\title{
Using a nitrilase for the surface modification of acrylic fibres
}

\author{
Teresa Matamá ${ }^{1 *}$, Filipa Carneiro ${ }^{1 *}$, Cristina Caparrós ${ }^{1}$, Georg M. Gübitz ${ }^{2}$ and Artur Cavaco-Paulo ${ }^{1}$ \\ 'University of Minho, Textile Engineering Department, Guimarães, Portugal \\ ${ }^{2}$ Graz University of Technology, Department of Environment Biotechnology, Graz, Austria
}

\begin{abstract}
The surface of an acrylic fibre was modified with a commercial nitrilase (EC 3.5.5.1). The effect of fibre solvents and polyols on nitrilase catalysis efficiency and stability was investigated. The nitrilase action on the acrylic fabric was improved by the combined addition of $1 \mathrm{M}$ sorbitol and $4 \%$ $N, N$-dimethylacetamide. The colour levels for samples treated with nitrilase increased $156 \%$ comparing to the control samples. When the additives were introduced in the treatment media, the colour levels increased $199 \%$. The enzymatic conversion of nitrile groups into the corresponding carboxylic groups, on the fibre surface, was followed by the release of ammonia and polyacrylic acid. A surface erosion phenomenon took place and determined the "oscillatory" behaviour of the amount of dye uptake with time of treatment. These results showed that the outcome of the application of the nitrilase for the acrylic treatment is intimately dependent on reaction media parameters, such as time, enzyme activity and formulation.
\end{abstract}

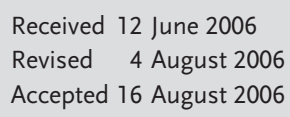

Supporting information available online

Keywords: Nitrilase $\cdot$ Nitrile hydrolysis · Polyacrylonitrile $\cdot$ Stability $\cdot$ Surface modification

\section{Introduction}

Polyacrylonitrile (PAN) fibres are characterised by a combination of desirable properties such as high resistance to outdoor exposure and chemicals, excellent elasticity, natural-like aesthetics properties and colour fastness. However, due to its hydrophobic nature, PAN fibres also exhibit undesirable properties such as uncomfortable hand and static charge accumulation [1, 2]. The quality and properties of acrylic fibres can be improved by chemical means, for instance, using co-monomers, additives and polymer blends, and by physical means (carried out at the polymerisation, dope preparation and spinning stages) [3]. The surface modification is also considered an important tool to improve the quality and the processing prop-

\footnotetext{
Correspondence: Professor Artur Cavaco-Paulo, University of Minho, Textile Engineering Department, 4800-058 Guimarães, Portugal E-mail: artur@det.uminho.pt Fax: +351523510293
}

\footnotetext{
Abbreviations: C.I., colour Index; DMA, N,N-dimethylacetamide; EG, ethylene glycol; K/S, Kubelka-Munk relationship (K, adsorption coefficient, S, scattering coefficient); o.w.f., of weight of fabric; PAA, polyacrylic acid; PAN, polyacrylonitrile; $\mathbf{T}_{\mathbf{g}}$, glass transition temperature; $\mathbf{T}_{\mathbf{d}}$, dyeing transition temperature
}

erties of natural and synthetic fibres [4]. Traditional processes used to modify polymer surfaces are based on the addition of strong chemical agents. The application of enzymes in polymer modification has major advantages compared to those agents, such as milder reaction conditions, easier control, specific non-destructive transformations, and environmental friendly processes [5].

The nitrile metabolism is present in plants, fungi and bacteria. The hydrolysis of nitrile groups to carboxylic groups is the most common pathway for the microbial degradation of nitrile compounds. This reaction can proceed through two distinct pathways: the direct conversion catalysed by nitrilase (EC 3.5.5.1) and the two-step conversion catalysed by nitrile hydratase (EC 4.2.1.84) and amidase (EC 3.5.1.4) [6].

Few studies on the modification of acrylic fibre with enzymes have been done and only the use of nitrile hydratases was reported $[4,6,7]$. The modification of nitrile surface groups into amide groups was accomplished by the action of nitrile hydratase from Rhodococcus rhodochrous [7], from Brevibacterium imperiale and Corynebacterium nitrilophilus [4] and from Arthrobacter

\footnotetext{
*These authors contributed equally to this work.
} 
sp. ECU1101 [8], where the modified PAN polymers became acid-dyeable fibres, with improved hydrophilicity.

Nitrilases are thiol enzymes that perform hydrolysis of the nitrile group to the corresponding acid and ammonia through the nucleophilic attack on the nitrile carbon atom by the thiol group of a catalytic cysteine residue $[9,10]$. Nitrilases belong to the first branch of the Nitrilase superfamily, which is the only one displaying true nitrilase activity $[11,12]$. So far, the described nitrilases consist of a single folded polypeptide, which, in general, aggregates to form the active enzyme [13]. The oligomeric form, in a few cases, is subjected to substrate activation or is dependent on the $\mathrm{pH}$, temperature and enzyme concentration [13]. A few structures of members of the Nitrilase super-family are already available. The subunits have a variant of the $\alpha+\beta$ fold: a compact $\alpha \beta \beta \alpha$ sandwich and it is assumed that the entire super-family uses a catalytic triad, consisting of conserved glutamic acid, lysine and cysteine residues $[12,14-17]$.

In this study, the modification of nitrile surface groups into carboxylic groups by the action of a commercial nitrilase, was investigated. The enzymatic modification of acrylic fibres is a heterogeneous process and, for that reason, requires longer treatments than one-phase catalysis. The reaction medium was manipulated to improve nitrilase catalysis efficiency on this substrate. First, the optimum $\mathrm{pH}$ and temperature were determined using a soluble substrate. Second, the effect of additives, like PAN solvents, on nitrilase stability and on enzymatic treatment of acrylic fibres was also studied. The solvents were introduced as fibre plasticizers to increase the accessibility of the fabric to the enzyme. Finally, to gain an understanding of the kinetics of the fibre surface modification, an enzymatic treatment was performed without additives.

To our knowledge, this is the first report on direct enzymatic modification of $-\mathrm{CN}$ groups into $-\mathrm{COOH}$ on fibres. It constitutes a promising approach to make the acrylic fibre more hydrophilic, enhancing the basic dye uptake of PAN-treated fabrics and producing surface-reactive chemical sites for other finishing processes.

\section{Materials and methods}

\subsection{Reagents}

The enzyme used in this work was a commercial nitrilase (EC 3.5.5.1): Cyanovacta Lyase, supplied by Novacta Byosystems Ltd. (Hatfield, UK). The Acrylic taffeta fabric used was a copolymer of PAN and 7\% vinyl acetate, with $82 \mathrm{~g} / \mathrm{m}^{2}$ and 36/36 ends/picks per cm, supplied by Fisipe (Lavradio Portugal). The cationic dye Basic Blue 9, C.I. 52015, was from Carlo Erba (Milan, Italy). All other reagents were laboratory grade reagents from SigmaAldrich (St. Louis, MO, USA).

\subsection{Nitrilase activity assay}

Nitrilase activity was determined by the quantification of the ammonia released into the reaction medium, using benzonitrile as the substrate. The reaction was started by the addition of $0.25 \mathrm{~mL}$ of a buffered nitrilase solution containing $0.08 \mathrm{mg} / \mathrm{mL}$ total protein to $0.25 \mathrm{~mL} 19.4 \mathrm{mM}$ benzonitrile in $50 \mathrm{mM}$ phosphate buffer $\mathrm{pH}$ 7.8. The mixture was incubated for 1-10 min in a water bath at $30^{\circ} \mathrm{C}$. The reaction was stopped by adding $0.1 \mathrm{~mL} 2 \mathrm{M} \mathrm{HCl}$. The ammonia was quantified using an enzymatic kit from Sigma Diagnostics (cat. no 171-A). All the assays were performed in triplicate. One unit of nitrilase activity was defined as one $\mu \mathrm{M}$ of $\mathrm{NH}_{3}$ released per minute.

\section{3 $\mathrm{pH}$ and temperature profile}

Nitrilase solutions with $0.08 \mathrm{mg} / \mathrm{mL}$ total protein were incubated for $10 \mathrm{~min}$ at $30^{\circ} \mathrm{C}$ in $300 \mathrm{mM}$ Britton-Robinson buffer solution of constant ionic strength. The $\mathrm{pH}$ range tested was between 4.5 and 10.6.

The effect of temperature was investigated within the range of $20^{\circ}-60^{\circ} \mathrm{C}$. Preparations of nitrilase with $0.08 \mathrm{mg} / \mathrm{mL}$ total protein were incubated in $50 \mathrm{mM}$ phosphate buffer at pH 7.8 for $10 \mathrm{~min}$, at the corresponding temperatures. The nitrilase activity was measured as described previously.

\subsection{Stability of nitrilase}

The operational stability of nitrilase was investigated in the presence of two organic solvents and several polyols. The enzyme was incubated at a final total protein concentration of $0.08 \mathrm{mg} / \mathrm{mL}$ in $50 \mathrm{mM}$ phosphate buffer pH 7.8 and different amounts (4-15\%) of $N, N$-dimethylacetamide (DMA) or $N, N$-dimethylformamide (DMF) or $1 \mathrm{M}$ polyol. The polyols studied were glycerol, sorbitol and ethylene glycol (EG). The enzyme was also incubated at the same final concentration with 4\% DMA and $1 \mathrm{M}$ sorbitol. For each assay, the final volume was $25 \mathrm{~mL}$, kept in 50-mL polypropylene containers. The control was identically prepared except that buffer substituted the enzyme. The incubation took place in a water bath at $30^{\circ} \mathrm{C}$ with an orbital agitation until the drop in nitrilase activity was above 50\%. The enzyme activity was assayed at appropriate time intervals as previously described.

\subsection{Effect of additives in the enzymatic treatment of acrylic fabric}

All samples of acrylic fabric used were previously washed to remove impurities. The washing was performed at $60^{\circ} \mathrm{C}$ with an aqueous solution of a non-ionic detergent $1.0 \mathrm{~g} / \mathrm{L}$ Lutensol AT25. After removing the detergent, the fabric was washed in distilled water and allowed to air dry. 
The treatment of acrylic fabric was carried out in stainless steel pots of $450 \mathrm{~mL}$ capacity in Rotawash MKIII (vertical agitation simulating European washing machines, from SDL International Ltd.), operating at $30^{\circ} \mathrm{C}$ and $20 \mathrm{rpm}$, for $116 \mathrm{~h}$. The samples of acrylic fabric, average weight $9 \mathrm{~g}$, were incubated with $24 \mathrm{U}$ nitrilase/g fabric in a final volume of $360 \mathrm{~mL} 50 \mathrm{mM}$ phosphate buffer $\mathrm{pH}$ 7.8. Three different media were tested: no additives, $4 \%$ DMA + 1 M sorbitol, and the control without enzyme and without additives.

After the enzymatic treatment, all fabric samples were immediately washed to remove the adsorbed protein. The samples were left under running tap water for several minutes and they were then washed with $2 \mathrm{~g} / \mathrm{L}$ sodium carbonate and distilled water, for $60 \mathrm{~min}$ each, at $60^{\circ} \mathrm{C}$.

\subsection{Enzymatic treatment of acrylic fabric}

All samples of acrylic fabric used were previously washed, as already described. The acrylic fabric was treated with $412 \mathrm{U}$ nitrilase/g fabric in $50 \mathrm{mM}$ phosphate buffer $\mathrm{pH}$ 7.8, at $40^{\circ} \mathrm{C}$. The acrylic fabric samples were treated in independent containers, one piece of fabric and bath solution for each time determination, in the Rotawash MKIII. Samples of acrylic fabric with an average weight of $2 \mathrm{~g}$ were incubated in a final volume of $100 \mathrm{~mL}$ of treatment solution, at 20 rpm for $0,2,4,8,24$, or 36 h.

After enzymatic treatment, all fabric samples were washed twice in $2 \mathrm{~g} / \mathrm{L}$ sodium carbonate for $20 \mathrm{~min}$, once in $4 \mathrm{~g} / \mathrm{L}$ Lutensol AT25 for $20 \mathrm{~min}$ and three times in distilled water for $25 \mathrm{~min}$, in the Rotawash at $70^{\circ} \mathrm{C}$. Before and in between the changes of the washing solution, the samples were left under running tap water.

\subsection{Quantification of total protein concentration}

Total protein in solution was quantified following Bradford methodology [18], using BSA as standard. All samples were measured in triplicate.

\subsection{Determination of ammonia concentration in the bath solutions}

Detection of ammonia in the reaction media of the first acrylic fabric treatment (see Section 2.5) was performed using the enzymatic kit from Sigma Diagnostics.

For the second nitrilase treatment (see Section 2.6), the Nessler method was adapted and applied to quantify ammonia [19]. Protein was previously precipitated using trichloroacetic acid and the supernatants were then subjected to $\mathrm{pH}$ neutralisation with $250 \mathrm{mM}$ sodium hydroxide. The standard solutions were prepared using anhydrous ammonium chloride and were submitted to the same protein precipitation procedure and $\mathrm{pH}$ adjustment. For the Nessler determination, $0.5 \mathrm{~mL}$ samples/standards were diluted with $4.5 \mathrm{~mL}$ distilled water in glass tubes and $10 \mu \mathrm{L}$ Rochelle salt (aqueous solution: 50\% potassium sodium tartrate tetrahydrated) were added. After mixing well, $0.2 \mathrm{~mL}$ Nessler reagent was added to each tube. The colour was allowed to develop for $10 \mathrm{~min}$ and the absorbance was registered at $425 \mathrm{~nm}$.

\subsection{Determination of polyacrylic acid concentration in the bath solutions}

Detection of polyacrylic acid (PAA) in the reaction medium was performed by absorption-colorimetric method using a kit from Hach Company, USA (cat. no. 22252-00 and no. 22257-00). The standards were prepared from aqueous solutions of PAA (average molecular weight $2000 \mathrm{~g} / \mathrm{mol}$ ).

\subsection{Determination of fabric weight differences}

The weight differences of the fabrics due to enzymatic treatment were determined by the weight difference between the dry fabrics before and after the enzymatic treatment. The fabric pieces were whipstitched with the same acrylic yarn. After the washing procedures, the samples were dried at $60^{\circ} \mathrm{C}$ for $3 \mathrm{~h}$ in a laboratory oven and they were then conditioned in a glass desiccator for $30 \mathrm{~min}$. This procedure was repeated until there was no further significant weight difference.

\subsection{Acrylic fabric staining with a basic dye}

After the enzymatic treatment, samples were competitively stained in duplicate with $1 \%$ of weight of fabric (o.w.f.) of Basic Blue 9, C.I.52015. The staining was performed in a lab-scale dyeing machine (AHIBA Spectradye, from Datacolor International) at 20-30 rpm, with a temperature gradient of $4^{\circ} \mathrm{C} / \mathrm{min}$. For a more detailed procedure, see Table 1.

After staining, all samples were washed twice with $4 \mathrm{~g} / \mathrm{L}$ Lutensol AT25, for 20 min each, and several times with water at $70^{\circ} \mathrm{C}$ in the Rotawash, until no more colour could be detected in the solution. The colour measurements were carried out with a reflectance spectrophotometer having a standard illuminant D65 (Spectraflash

Table 1. Staining conditions for acrylic fabrics with Basic Blue 9, C.I. 52015, according to each enzymatic treatment performed

\begin{tabular}{cccc}
\hline Enzymatic treatment & Temperature $\left({ }^{\circ} \mathbf{C}\right)$ & Fabric weight $(\mathrm{g})$ & Staining volume $(\mathbf{m L})$ \\
\hline 1st treatment & 80 & 1 & 100 \\
2nd treatment & $70,75,80,90$ & 1.7 & 75 \\
\hline
\end{tabular}


600 Plus, from Datacolor International). The colour strength was evaluated as K/S at the maximum absorption wavelength $(660 \mathrm{~nm})$. The ratio between absorption $(\mathrm{K})$ and scattering $(\mathrm{S})$ is related to reflectance data by applying Kubelka-Munk's law at each wavelength, and it is proportional to dye concentration [20].

\section{Results and discussion}

\section{1 $\mathrm{pH}$ and temperature profile of nitrilase activity}

Enzymes as proteins have properties that are quite dependent on the environment. Among other factors, slight changes on $\mathrm{pH}$ and temperature can affect the performance of an enzyme. The effect of the solution $\mathrm{pH}$ on the initial activity of nitrilase was studied within the $\mathrm{pH}$ range of 4.5-10.6. Nitrilase was active in a wide $\mathrm{pH}$ range, and kept more than $75 \%$ of its maximum activity between 7.5 and 10.6. The maximum initial activity of nitrilase was observed in the $\mathrm{pH}$ range 8-10, with $\mathrm{pH} 9$ being the optimum $\mathrm{pH}$ value, for which the activity was $15 \mathrm{U} / \mathrm{mg}$ total protein. Nitrilases are in general very labile enzymes, especially at high purity levels [21-23], with pH optimum values ranging between 7.5 and $8[6,13]$. The commercial enzyme used throughout this work is supplied as cell preparation and, according to the results obtained, this nitrilase has a relatively high optimum $\mathrm{pH}$, resembling nitrilases from fungi and from the bacteria Klebsiella ozaenae $[24,25]$. According to the suppliers, the enzyme solution should be maintained in the $\mathrm{pH}$ range 7-8; thus pH 7.8 was chosen to perform all the enzymatic treatments.

The temperature effect on the initial nitrilase activity was studied between $20^{\circ}$ and $60^{\circ} \mathrm{C}$. The maximum formation of ammonia occurred between $40^{\circ}$ and $45^{\circ} \mathrm{C}$. The highest value of activity was $33 \mathrm{U} / \mathrm{mg}$, obtained at $45^{\circ} \mathrm{C}$. Above this temperature, there was a sharp decrease in nitrilase activity. In the literature, the optimal temperatures for mesophilic nitrilases vary considerably but there is some agreement in considering this group of enzymes very sensitive to this parameter [26]. The stability range of temperatures is often below the optimum values.

\subsection{Stability of nitrilase}

Operational stability, defined as the persistence of enzyme activity under the conditions of use, was studied before applying the enzyme to acrylic fabric treatment [27]. The effect of the addition of two organic solvents and polyols on nitrilase activity was studied by comparing the half-life time, as a measure of stability. The values of halflife time were calculated from first order exponentional decay fitting of data, using OriginPro 7.5 SRO (OriginLab Corporation, Northampton, USA). The decay of nitrilase activity obeyed to this exponential model of enzyme deactivation.

The addition of both organic solvents, DMA and DMF, to the enzyme solution decreased the initial activity and the half-life time of nitrilase. For many enzymes, deactivation in homogeneous water-organic solvent mixtures may be due to the disruption of the quaternary structure, disruption of the protein hydrophobic core and/or to the water stripping [28]. This effect was more pronounced as the organic co-solvent concentration increased. The decrease in the half-life time is almost linear with the increase in the organic solvent concentration (Table 2). Comparing the two solvents, the decrease of nitrilase activity was faster and more pronounced when DMF was added. Therefore, DMA should be used instead of DMF for enzymatic treatments of acrylic fibre. The investigated organic solvents were chosen because of their action on the fibre structure. They are known solvents of PAN and they are commonly used in industrial production of acrylic fibre [3, 29]. Their plasticizer function disturbs the regular structure of the polymer, reducing the magnitude of interchain bonding, which should aid the accessibility to the enzyme, improving its action on the fibre.

The initial activity of nitrilase increased in the presence of all the studied polyols, particularly, sorbitol and glycerol. This effect could be due to the better solubility of the substrate benzonitrile in the media containing sorbitol and glycerol, compared to EG. The highest half-life time values were obtained with the addition of sorbitol and EG. Sorbitol showed the best performance as a nitrilase stabiliser for long-term treatments. The half-life time increased almost three times (from 15 to $44 \mathrm{~h}$ ) in the presence of sorbitol. It has been found that the addition of high concentrations (usually higher than $1 \mathrm{M}$ ) of some low mo-

Table 2. Influence of organic solvents and polyols on initial activity and half-life time of nitrilase, at $30^{\circ} \mathrm{C}$ and $\mathrm{pH} 7.8$. The initial activity and the half-life time for the control were $12.6 \mathrm{U} / \mathrm{mg}$ and $15 \mathrm{~h}$, respectively).

\begin{tabular}{lccc}
\hline \multicolumn{2}{c}{ Assay conditions } & $\begin{array}{c}\text { Initial } \\
\text { activity (\%) }\end{array}$ & $\begin{array}{c}\text { Half-life } \\
\text { time (\%) }\end{array}$ \\
\hline Control & No additives & 100 & 100 \\
\hline DMF & $4 \%$ & 87 & 30 \\
& $10 \%$ & 78 & 19 \\
& $15 \%$ & 59 & 9 \\
\hline DMA & $4 \%$ & 84 & 90 \\
& $10 \%$ & 89 & 55 \\
& $15 \%$ & 87 & 19 \\
\hline Polyols (1 M) & Glycerol & 122 & 101 \\
& Sorbitol & 122 & 294 \\
& EG & 107 & 160 \\
\hline $4 \%$ DMA + 1 M sorbitol & & 105 & 249 \\
\hline
\end{tabular}

a) The SDs for the initial activity and half-life time values were $\leq 5 \%$ and $\leq 7 \%$, respectively 
lecular weight compounds in solution stabilises the native conformation of globular proteins [30]. This stabilising effect is related to the general role of polyols as a water-structure maker [30, 31].

A combined effect of the organic solvent and the stabiliser was studied in order to check the possibility of a compromise between an increase in the accessibility of the nitrilase to acrylic fibre and a good operational stability of the enzyme. The least deleterious condition studied was 4\% DMA. The addition of $1 \mathrm{M}$ sorbitol to this medium proved to be beneficial (Table 2). The initial activity was slightly improved and the half-life time, although shorter than the one obtained in the presence of only sorbitol, was still $249 \%$ of the half-life time for the control (no additives). The half-life time of nitrilase without additives increased from 15 to $38 \mathrm{~h}$ in the presence of the additives. Therefore, these conditions were chosen for the enzymatic treatment of acrylic fabric.

\subsection{Effect of additives on the modification of acrylic surface with nitrilase}

The hydrolysis of nitrile groups from the acrylic fibre should result in the formation of carboxylic groups at the fibre surface and in the release of ammonia to the treatment solution.

The formation of carboxylic groups at the fibre surface was evaluated by staining the fabric with a basic dye, which has a cationic group able to establish ionic bonds with anionic groups on the fibre. If nitrilase is able to modify some of the nitrile groups into carboxylic groups, at the surface, then more dye can be absorbed into the fibre, and this could be seen as an increase in K/S. The staining 'titration' methodology has already been reported [32, 33] and proved to be a valuable and a very sensitive qualitative method.

For samples treated with nitrilase without additives, the K/S value increased $156 \%$ at the dyeing temperature of $80^{\circ} \mathrm{C}$ (Table 3). The dye uptake was even more pronounced by the addition of sorbitol and DMA to the enzymatic treatment. At $80^{\circ} \mathrm{C}$, the increase of the staining level was $17 \%$, when compared with the nitrilase treatment without additives. This confirms the improved catalysis performance provided by the additives, probably through an increase in the fibre surface area available for the nitrilase attack.

Evidence of hydrolysis was also obtained by the formation of ammonia. The ammonia concentrations are reported in Table 3. It was not possible to determine the ammonia in the solution from the treatment with additives, because they interfered with the kit reagents.

From the expected reaction products, the weight of acrylic fabric should, in theory, increase. The results obtained showed the opposite (Table 3). There was a slight weight loss instead of a weight gain.
Table 3. Effect of the additives on the enzymatic modification of acrylic fabric. The parameters evaluated were the staining level of acrylic fabric, measured by $\mathrm{K} / \mathrm{S}$ values, the fabric weight loss and the ammonia release. The acrylic fibre was treated with $24 \mathrm{U}$ nitrilase/g fabric, at $\mathrm{pH} 7.8$ and $30^{\circ} \mathrm{C}$

\begin{tabular}{lccc}
\hline & & \multicolumn{2}{c}{ Enzymatic treatment } \\
\cline { 3 - 4 } & Control & No additives & DMA + sorbitol \\
\hline $\mathrm{K} / \mathrm{S}_{660 \mathrm{~nm}}{ }^{\mathrm{a})}$ & 9.8 & 25.1 & 29.3 \\
${\left.\text { Weight loss }(\%)^{\mathrm{a}}\right)}$ & 0.3 & 0.4 & 0.9 \\
Ammonia $(\mathrm{mM})^{\mathrm{a})}$ & 0 & 15.3 & $\mathrm{nd}$ \\
\hline
\end{tabular}

a) The SDs for the $\mathrm{K} / \mathrm{S}$, weight loss and ammonia concentration values were $\leq 10 \%, \leq 15 \%$ and $\leq 11 \%$, respectively.

The above results suggested that some modified polymer chains could be solvated and could become soluble in the form of PAA or a copolymer of acrylic acid and acrylonitrile. To verify this hypothesis, another assay was performed and samples of acrylic fabric and treatment solutions were collected at different times of enzymatic incubation. This study is reported in the next section.

\subsection{Kinetics studies of acrylic surface modification}

As in all heterogeneous catalysis, it is necessary to consider two general steps for the nitrilase catalysis to occur: the physical adsorption of nitrilase to acrylic fibre surface and the formation of the enzyme/substrate complex and consequent hydrolysis of the nitrile group.

The protein adsorption was indirectly calculated by a decrease in total protein remaining in the treatment solution (Fig. 1). In the first $8 \mathrm{~h}$ of treatment, there was a sharp decrease in the protein content in the treatment solution. Afterwards, the equilibrium around an average value was reached, with some oscillations due to alternating adsorption and desorption phenomena [34]. The equilibrium value of protein concentration in the solution was about $9 \mathrm{mg} / \mathrm{L}$, meaning a total protein adsorption of $80 \%$, at $40^{\circ} \mathrm{C}$.

There was no significant ammonia release before $8 \mathrm{~h}$ of treatment (Fig. 1). It is interesting to notice that the release of ammonia into treatment solutions was coincident with the achievement of the adsorption equilibrium. This lag phase is also seen in homogeneous catalysis of nitrilases whose activity onset depends on the assembly of its oligomeric active form [21]. The ammonia release is a good indicator of successful nitrilase catalysis, which should render an improvement of the acrylic dyeability. It also shows that a certain amount of those $80 \%$ of total protein adsorption must be nitrilase and that the enzyme is able to recognize the nitrile groups of acrylic fabric as the substrate.

The linear release of ammonia also implies the absence of activity decay during the $36 \mathrm{~h}$ of treatment. Since its half-life time in solution was $15 \mathrm{~h}$, it is feasible to as- 


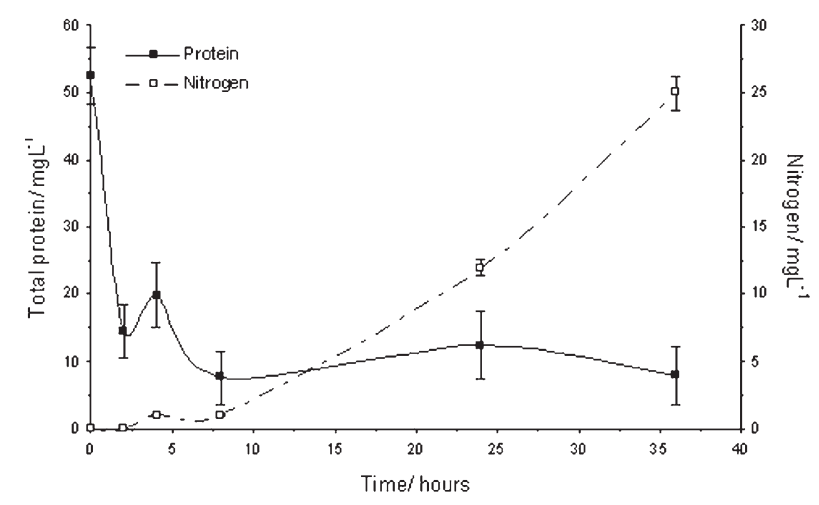

Figure 1. Total protein and nitrogen concentrations in the treatment solutions. The acrylic fibre was treated with $412 \mathrm{U}$ Cyanovacta Lyase/g fabric, at $\mathrm{pH} 7.8$ and $40^{\circ} \mathrm{C}$.

sume that the adsorption of the enzyme to acrylics led to an increase in its stability, resembling the immobilization procedures used to stabilise proteins.

In Fig. 2, the values of K/S are represented as a percentage of the initial value. The relative $\mathrm{K} / \mathrm{S}$ had a waving behaviour with incubation time. This behaviour was attenuated with the increase in the staining temperature, as expected. Enzymes are large molecules and they will not penetrate inside the tight structure of PAN fibres. Therefore, the chemical changes catalysed by nitrilase are located at the surface. At lower temperatures, the adsorption of dye occurs mostly at the fibre surface where the enzymatic catalysis takes place, producing different $\mathrm{K} / \mathrm{S}$ values between samples treated with enzyme and controls. The significant raise in dye diffusion that occurs at or about the glass transition temperature $\left(\mathrm{T}_{\mathrm{g}}\right)$ is often referred as the dyeing transition temperature $\left(\mathrm{T}_{d}^{g}\right)$ [3]. Both transition temperatures, $\mathrm{T}_{\mathrm{g}}$ and $\mathrm{T}_{\mathrm{d}}$, indicate the onset of segmental mobility of the polymer chains and the consequent increase of the free volume within the polymer [3]. Approaching these temperatures, the colour depth increases sharply for both enzymatic treated and untreated samples and camouflages the differences in K/S due to superficial changes. This is the reason for the observed decrease in the amplitude of the oscillation of relative $\mathrm{K} / \mathrm{S}$ with increasing staining temperatures $\left(70-80^{\circ} \mathrm{C}\right)$. At $90^{\circ} \mathrm{C}$, which is above $\mathrm{T}_{\mathrm{d}}$, the differences are absent.

The oscillation of relative K/S values with time of treatment could be explained assuming that above a threshold conversion of nitrile groups into carboxylic groups, the polymer chains would be more stable in solution and would be detached from the surface of the fibre. The modification of $\mathrm{CN}$ into $\mathrm{COOH}$ groups could create some instability in the arrangement of PAN chains at the fibre surface, mainly due to steric hindrance and $\mathrm{pH}$-dependent charge repulsion. It was possible to detect increasing concentrations of PAA in treatment solutions (Fig. 3). The re-

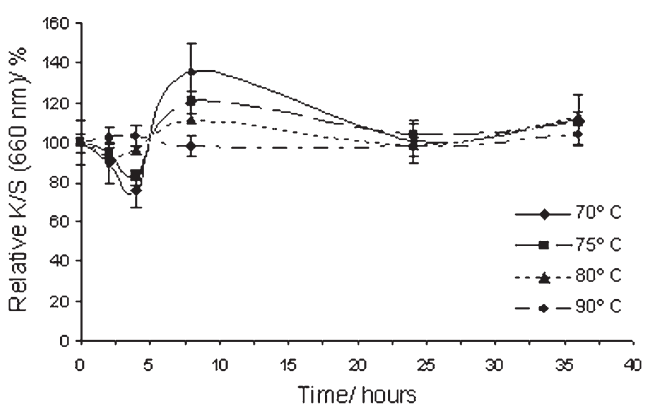

Figure 2. Relative $\mathrm{K} / \mathrm{S}$ values for acrylic fabric treated with nitrilase Cyanovacta Lyase, at $\mathrm{pH} 7.8$ and $40^{\circ} \mathrm{C}$. Samples and controls were competitively dyed at $70^{\circ}, 75^{\circ}, 80^{\circ}$ and $90^{\circ} \mathrm{C}$. Relative $\mathrm{K} / \mathrm{S}$ is calculated as $\left(\mathrm{K} / \mathrm{S}_{\text {enzyme }}\right) /\left(\mathrm{K} / \mathrm{S}_{\text {control }}\right)(\%)$.

moval of carboxylic groups from the surface of the fabric could be the cause of the lower points on the K/S curve. When the PAA macromolecules leave the surface, the underneath PAN chains are exposed to further nitrilase catalysis. This leads to an increasing number of carboxylic groups, thus, to an increase of $\mathrm{K} / \mathrm{S}$, until the threshold value for chain solubilization is again achieved.

A maximum K/S point was observed for the $8 \mathrm{~h}$ treatment. For longer incubation periods, the "wave amplitude" tends to decrease, as the "length" tends to increase with time. This could be related to modifications in the fibre surface, since there was not an activity decay of the enzyme. However, the particular phenomenon that explains why this happens is still unclear.

The hypothetical model of "surface erosion" of acrylic fibre, described here, is very similar to the ones applicable for synthetic polymers biodegradation [35, 36]. The acrylic fibre surface is depleted layer by layer, depending on factors such as micro-structural properties of PAN copolymers, molar mass of the polymer chains, enzyme adsorption, nitrilase deactivation, removal and dissolution of products.

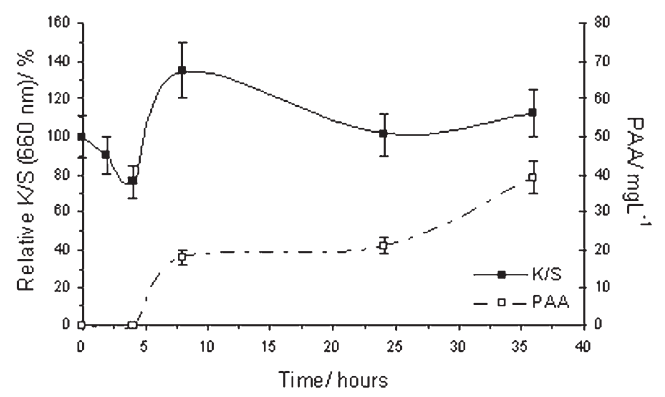

Figure 3. Relative $\mathrm{K} / \mathrm{S}$ for acrylic fabric dyed at $70^{\circ} \mathrm{C}$ and polyacrylic acid concentration in the treatment solutions. The acrylic fibre was treated with $412 \mathrm{U}$ Cyanovacta Lyase/g fabric, at $\mathrm{pH} 7.8$ and $40^{\circ} \mathrm{C}$. 


\section{Concluding remarks}

To our knowledge, this is the first report of the biomodification of acrylic fabric with nitrilase. Previous studies used another class of enzymes, nitrile hydratases $[4,6,7]$. The modification of the fibre surface was demonstrated by the improvement in the basic staining of the fabric and, indirectly, by the ammonia release into the treatment solution.

In spite of the increasing interest in nitrilase enzymatic systems and its successful industrial applications using whole cells $[37,38]$, there is still much to discover in the understanding and improvement of the nitrile conversion by purified or semi-purified nitrilases. The work reported here also evaluates the stabilisation efficiency of various additives and the influence of two organic Co-solvents in the activity of a commercial nitrilase. From the additives studied, the best stabilising performance was induced by sorbitol. Another important aspect is the fact that the organic solvent DMA, used in acrylic fibre industry, revealed no significant loss in initial enzyme activity, when used in small amounts. The addition of sorbitol and DMA proved to be beneficial for the acrylic surface modification with nitrilase.

It has also been demonstrated in this study that a successful application of nitrilase to acrylic surface modification would be dependent on the control of important factors like time and enzyme activity. The nitrilase action seems to induce "surface erosion" of PAN fibres, by the dissolution of the modified polymer molecules. This hypothesis is confirmed by the detection of PAA in the treatment solutions.

Further studies will be necessary to evaluate the impact of nitrilase activity on the physical properties of the fabric and to assess if some amide groups are also produced as by-products of nitrilase hydrolysis.

From the above considerations, the stabilised nitrilase appears to have potential in textile industry for the modification of PAN fibres. The wet spinning would be the most adequate industrial process for the introduction of such enzymatic treatment, although it would demand a very fast enzymatic modification (a few minutes). The accessibility of the fibre would be greater than that of the woven fabric used in this study. If the application of the enzyme occurred when the fibre is still in a gel state, a considerable reduction in the time needed to maximize the enzymatic conversion into carboxylic groups could occur. In addition, after coagulation, there are other possible stages for the application of an enzymatic treatment, during which several finishing processes normally take place. The nitrilase stability would not be so compromised by the amount of solvent present as in earlier stages. In any case, a careful study is needed to evaluate the feasibility of such application, but the work reported here gives encouraging perspectives.
This work was supported by the Biosyntex Project, no. G5RD 2000-30110, from the European Community under the 'Competitive and Sustainable Growth' Program, and by the PhD grant SFRH/BD/13423/2003, from Fundação para a Ciência e a Tecnologia.

\section{References}

[1] Lulay, A., Apparel end uses, in: Masson, J. C. (Ed.), Acrylic Fiber Technology and Applications, Marcel Dekker, New York 1995, pp. 313-339.

[2] Frushour, B. G., Knorr, R. S., Acrylic fibres, in: Lewin, M., Pearce, E. M. (Ed.), International Fiber Science and Technology Series/ 15-Handbook of Fibre Chemistry, Marcel Dekker, New York 1998, pp. 869-1070.

[3] Burkinshaw, S. M., Chemical Principles of Synthetic Fibre Dyeing, Blackie Academic \& Professional, London 1995.

[4] Battistel, E., Morra, M., Marinetti, M., Enzymatic surface modification of acrylonitrile fibers. Appl. Surf. Sci. 2001, 177, 32-41.

[5] Gübitz, G. M., Cavaco-Paulo, A., New substrates for reliable enzymes: enzymatic modification of polymers. Curr. Opin. Biotechn. 2003, 14, 577-582.

[6] Banerjee, A., Sharma, R., Banerjee, U. C., The nitrile-degrading enzymes: current status and future prospects. Appl. Microbiol. Biotechnol. 2002, 60, 33-44.

[7] Tauber, M. M., Cavaco-Paulo, A., Robra, H., Gübitz, G. M., Nitrile hydratase and amidase from Rhodococcus rhodochrous hydrolyze acrylic fibers and granular polyacrylonitriles. Appl. Environ. Microbiol. 2000, 66, 1634-1638.

[8] Wang, N., Xu, Y., Lu, D. N., Enzymatic surface modification of acrylic fibre. AATCC Rev. 2004, 4, 28-30.

[9] Mahadevan, S., Thimann, K., Nitrilase: II. Substrate specificity and possible mode of action. Arch. Biochem. Biophys. 1964, 107, 62-68.

[10] Kobayashi, M., Goda, M., Shimizu, S., Nitrilase catalyzes amide hydrolysis as well as nitrile hydrolysis. Biochem. Biophys. Res. Commun. 1998, 253, 662-666.

[11] Pace, H. C., Brenner, C., The nitrilase superfamily: classification, structure and function. Genome Biol. 2001, 2, 1-9.

[12] Brenner, C., Catalysis in the nitrilase superfamily. Curr. Opin. Struct. Biol. 2002, 12, 775-782.

[13] O'Reilly, C., Turner, P. D., The nitrilase family of CN hydrolysing enzymes - a comparative study. J. Appl. Microbiol. 2003, 95, 1161-1174.

[14] Pace, H. C., Hodawadekar, S. C., Draganescu, A., Huang, J. et al., Crystal structure of the worm NitFhit Rosetta Stone protein reveals a Nit tetramer binding two Fhit dimmers. Curr. Biol. 2000, 10, 907-917.

[15] Nakai, T., Hosegawa, T., Yamashita, E., Yamamoto, M. et al., Crystal structure of N-carbamyl-D-amino acid amidohydrolase with a novel catalytic framework common to amidohydrolases. Structure 2000, 8 , 729-739.

[16] Kumaran, D., Eswaramoorthy, S., Gerchman, S. E., Kycia, H. et al., Crystal structure of a putative CN hydrolase from yeast. Proteins 2003, 52, 283-291.

[17] Sewell, B. T., Berman, M. N., Meyers, P. R., Jandhyala, D., Benedik, M. J., The cyanide degrading nitrilase from Pseudomonas stutzeri AK61 is a two fold symmetric, 14-subunit spiral. Structure 2003, 11, 1413-1422.

[18] Bradford, M. M., A rapid and sensitive method for the quantification of microgram quantities of protein utilizing the principle of proteindye binding. Anal. Biochem. 1976, 72, 248-254. 
[19] Greenberg, A. E., Clesceri, L. S., Eaton, A. D., Standard methods for the examination of water and wastewater, American Public Health Association, New York 1992, pp. 4.75-4.80.

[20] Kuehni, R. G., Color: an Introduction to Practice and Principles, John Wiley \& Sons, New York 1997, pp. 109-119.

[21] Harper, D. B., Microbial metabolism of aromatic nitriles - enzymology of C-N cleavage by Nocardia sp. (rhodochrous group) N.C.I.B. 11216. Biochem. J. 1977, 165, 309-319.

[22] Harper, D. B., Characterization of a nitrilase from Nocardia sp. (rhodochrous group) N.C.I.B. 11215, using p-hydroxybenzonitrile as sole carbon source. Int. J. Biochem. 1985, 17, 677-683.

[23] Bandyopadhyay, A. K., Nagasawa, T., Asano, Y., Fujishiro, K. et al., Purification and characterization of benzonitrilases from Arthrobacter sp. Strain J-1. Appl. Environ. Microbiol. 1986, 51, 302-306.

[24] Harper, D. B., Fungal degradation of aromatic nitriles - enzymology of C-N cleavage by Fusarium solani. Biochem. J. 1977, 167, 685-692.

[25] Stalker, D. M., Malyj, L. D., McBride, K. E., Purification and properties of a nitrilase specific for the herbicide Bromoxynil and corresponding nucleotide sequence analysis of the bxn gene. J. Biol. Chem. 1988, 263, 6310-6314.

[26] Cowan, D., Cramp, R., Pereira, R., Graham, D., Almatawah, G., Biochemistry and biotechnology of mesophilic and thermophilic nitrile metabolizing enzymes. Extremophiles 1998, 2, 207-216.

[27] Ó'Fágáin, C., Enzyme stabilization - recent experimental progress. Enzyme Microb. Technol. 2003, 33, 137-149.

[28] Castro, G. R., Knubovets, T., Homogeneous biocatalysis in organic solvents and water-organic mixtures. Crit. Rev. Biotechn. 2003, 23, 195-231.

[29] Capone, G. J., Wet-spinning technology, in: Masson J. C. (Ed.), Acrylic Fiber Technology and Applications, Marcel Dekker, New York 1995, pp. 69-104.
[30] Xie, G., Timasheff, S. N., Mechanism of the stabilization of ribonuclease A by sorbitol: preferential hydration is greater for the denatured than for the native protein. Protein Sci. 1997, 6, 211-221.

[31] Timasheff, S. N., Solvent stabilization of protein structure, in: Shirley, B. A. (Ed.), Methods in Molecular Biology - Protein Stability and Folding: Theory and Practice, Human Press, Totowa 1995, pp. 253-269.

[32] Silva, C. M., Carneiro, F., O’Neill, A., Fonseca, L. P. et al., Cutinase a new tool for biomodification of synthetic fibers. J. Polym. Sci., Part A: Polym. Chem. 2005, 43, 2448-2450.

[33] Silva, C., Matamá, T., Gübitz, G. M., Cavaco-Paulo, A., Influence of organic solvents on cutinase stability and accessibility to polyamide fibres. J. Polym. Sci., Part A: Polym. Chem. 2005, 43, 2749-2753.

[34] Azevedo, H., Bishop, D., Cavaco-Paulo, A., Effects of agitation level on the adsorption, desorption, and activities on cotton fabrics of full length and core domains of EGV (Humicola insolens) and CenA (Cellulomonas fimi). Enzyme Microb. Technol. 2000, 27, 325-329.

[35] Marten, E., Müller, R. J., Deckwer, W. D., Studies on the enzymatic hydrolysis of polyesters: I. Low molecular mass model esters and aliphatic polyesters. Polym. Degrad. Stab. 2003, 80, 485-501.

[36] Marten E., Müller, R. J., Deckwer, W. D., Studies on the enzymatic hydrolysis of polyesters: II. Aliphatic-aromatic copolyesters. Polym. Degrad. Stab. 2005, 88, 371-381.

[37] Kobayashi, M., Shimizu, S., Versatile nitrilases: nitrile-hydrolysing enzymes. FEMS Microbiol. Lett. 1994, 120, 217-224.

[38] Hughes, J., Armitage, Y. C., Symes, K., Application of whole cell rhodococcal biocatalysts in acrylic polymer manufacture. Antonie van Leeuwenhoek 1998, 74, 107-118. 